\title{
Importance of local and long-distance Heterobasidion irregulare aerial basidiospore dispersal for future infection centres in thinned red pine plantations in Quebec
}

\author{
by Jean $A$. Bérubé ${ }^{*}$, Amélie Potvin ${ }^{1}$ and Donald Stewart ${ }^{1}$
}

\begin{abstract}
Heterobasidion irregulare is a basidiomyceteous forest pathogenic fungus which causes a root disease capable of killing large trees. Infection probability is proportional to the density of aerial basidiospores infecting freshly cut stumps. The purpose of this study was to quantify for the first time $H$. irregulare aerial basidiospore density in southern Québec and to determine the importance of a local basidiospore load from a nearby infested plantation. Spore counts from automated rotary arm spore collectors were assayed using a ribosomal ITS TaqMan real-time PCR detection assay. Cumulative basidiospore deposits on a $30-\mathrm{cm}$ stump were estimated to be highest in the infected plantation with 2.37 basidiospores per stump, with decreasing count of 0.52 basidiospores at a $500-\mathrm{m}$ distance and 0.46 basidiospores at a $1.5-\mathrm{km}$ distance. At $5 \mathrm{~km}$ from the infected plantation, the number of basidiospores deposited on a stump was 0.22 , a value similar to those at distances of 25 and $140 \mathrm{~km}$. Since a single Heterobasidion basidiospore may travel as far as $500 \mathrm{~km}$, the level detected at $5 \mathrm{~km}$ may represent the background basidiospore load resulting from long-distance dispersal, and basidiospores from a nearby infected plantation are unlikely to be an added risk of infection to plantations located more than $5 \mathrm{~km}$ away. Long distance aerial basidiospore dispersal will remain for now the most important constant source of infectious $H$. irregulare in Québec. Despite the very low risk level per stump in this study, the large number of trees thinned annually warrants that stump treatment with Rotstop ${ }^{\oplus} \mathrm{C}$ is still the best strategy, especially in valuable plantations.
\end{abstract}

Key words: basidiomycetes, basidiospore deposition, biological control, forest pathology, ribosomal ITS, root rot, Rotstop

\section{RÉSUMÉ}

Heterobasidion irregulare est un champignon pathogène forestier capable de tuer des arbres de grand diamètre et le risque d'infection est proportionnel à la quantité de basidiospores aériennes qui se déposeront sur les souches des pins rouges fraîchement coupées. Le but de cette étude était de quantifier pour la première fois la densité de basidiospores aériennes dans le sud du Québec et déterminer l'importance de basidiospores locales provenant d'une plantation infectée située à proximité. Le comptage des basidiospores capturées par un collecteur à bras rotatif sest fait à laaide de PCR en temps réel avec des sondes TaqMan visant l'ITS de l'ADN ribosomique. Le compte cumulatif de basidiospores sur une souche de 30 $\mathrm{cm}$ était maximal, soit 2,37 basidiospores par souche, dans la plantation infectée, suivi de 0,52 basidiospores à $500 \mathrm{~m}$ de distance et de 0,46 basidiospores à $1,5 \mathrm{~km}$. À $5 \mathrm{~km}$ de la plantation infectée, le nombre cumulatif de basidiospores était de 0,22 , une valeur semblable à celles se trouvant à 25 et $140 \mathrm{~km}$. Puisque les basidiospores de Heterobasidion sont reconnues pour voyager sur des distances allant jusquà $500 \mathrm{~km}$, le nombre cumulatif de basidiospores à $5 \mathrm{~km}$ peut être considéré comme le niveau basal résultant de la propagation sur une longue distance et les basidiospores produites localement ont peu de chance d'induire un risque supplémentaire d'infection à une distance de plus de $5 \mathrm{~km}$. La propagation des basidiospores à longue distance restera dans un avenir rapproché la principale source de basidiospores infectieuses de $\mathrm{H}$. irregulare dans la province de Québec. Malgré les faibles taux cumulatifs relevés, le grand nombre d’arbres coupés annuellement lors déclaircies porte à croire que le traitement des souches avec Rotstop ${ }^{\circ} \mathrm{C}$ reste la meilleure stratégie, surtout dans les plantations de grandes valeurs.

Mots-clés: basidiomycètes, depôt de basidiospores, ITS ribosomique, carie racinaire, pathologie forestière, lutte biologique, Rotstop

\footnotetext{
${ }^{1}$ Natural Resources Canada, Canadian Forest Service, Laurentian Forestry Centre, Ste-Foy, Québec, QC, G1V 4C7, Canada. * corresponding author: jean.berube@canada.ca
} 


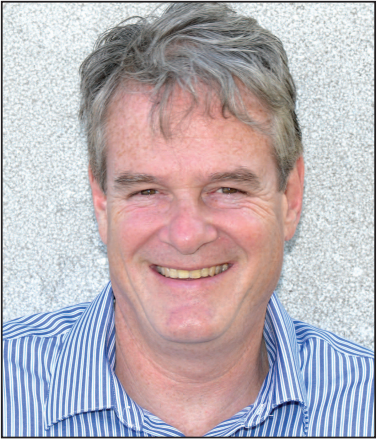

Jean A. Bérubé

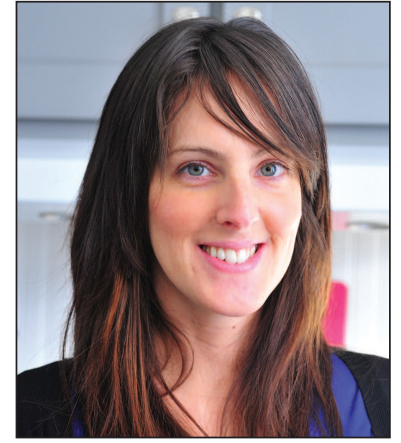

Amélie Potvin

\section{Introduction}

Heterobasidion irregulare (Underw.) Garbel. \& Otrosina is a basidiomyceteous pathogen that produces sporophores decomposing stumps and dead trees. This fungus causes a root disease capable of killing large trees. The primary mode of infection of this aggressive pathogen is through aerial basidiospores and successful infections occur when the basidiospores are deposited on freshly-cut stump surfaces. Once $H$. irregulare is established, it will colonize the roots and spread between infected and non-infected roots via root grafts to further its spread among uninfected trees within a plantation.

In Canada, Jorgensen (1956) was the first to report the discovery of $H$. irregulare on red pine (Pinus resinosa Ait.) at St. Williams in Ontario. By 1968, the pathogen had spread further north near Ottawa (Sippell et al. 1968, Punter 1970). This disease has since been found in Québec in 1989 (Laflamme and Blais 1995) and new infection centres have been found in 14 plantations at eight locations in different southern regions of Québec (MFFP 2016). In eastern Canada, the pathogen is found mainly in red pine plantations in southern Ontario and Québec and is progressing northward and eastward.

Red pine plantations occupy a large area of the productive forested land in southern Québec where more than 10000 ha have been planted since the 1970s (MFFP 2015). Periodic thinning of plantations is a silvicultural prescription recommended to increase stand quality and volume. However, thinning makes these plantations vulnerable to $H$. irregulare infection as it produces fresh stumps that are infection courts for the disease in valuable plantations.

Eastern Canada is still at the beginning of a possible regional epidemic and the probability of new infections would be described as proportional to the density of aerial basidiospores (Stambaugh et al. 1962, Gonthier et al. 2005). In Europe, the probability of infection on a freshly cut stump can be as high as $100 \%$ in many countries (Vollbrecht et al. 1995). While the basidiospores responsible for past infections in Québec were most likely caused by long-distance dispersal (up to $500 \mathrm{~km}$; Kallio (1970), basidiospores from local infected plantations most probably play an important role in future infections.

The purpose of this study was to quantify for the first time H. irregulare aerial basidiospore density in southern Québec

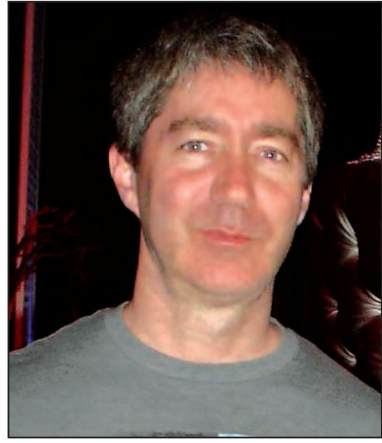

Donald Stewart and to determine the importance of local basidiospore load from nearby infested plantations.

\section{Methods and Materials}

Five automated rotary arm spore collectors were deployed in the field in late September 2014 from the most easterly known infected plantation located in SainteClotilde-de-Horton ( $45^{\circ} 59^{\prime}$ $\left.35.65^{\prime \prime} \mathrm{N}, 72^{\circ} 11^{\prime} 35.56^{\prime \prime} \mathrm{W}\right)$. The plantation was heavily damaged during the 1998 ice storm and a damaged tree removal protocol was carried out the following summer. Heterbasidion irregulare-related mortality was first detected in 2009 and a mortality centre continues to expand. Infected trees have been removed periodically; however, infected stumps were left on site. Spore collectors (Compagnie de Recherches Phytodata Inc., StEdouard, QC) were installed at the end of September 2014 in an eastward transect beginning in the plantation, then at $500 \mathrm{~m}, 1.5 \mathrm{~km}, 5 \mathrm{~km}, 25 \mathrm{~km}$ and $140 \mathrm{~km}$ from the plantation. Spore collectors were programmed to spin their rotary arm for $5 \mathrm{~min}$ every $90 \mathrm{~min}$, and sticky rods $(1.5 \mathrm{~mm} \mathrm{X} 1.5$ mm X $3 \mathrm{~cm}$ ) were collected every week from September 29 to November 15 , for a total of $560 \mathrm{~min}(9.33 \mathrm{~h})$ of exposure for each rod/week.

One sticky rod per sample was placed in a separate extraction tube. DNA extraction was then performed following the protocol developed by Lamarche et al. (2016). Briefly, $1 \mathrm{ml}$ of hexane was added to each tube, vortexed for 30 seconds and rods removed. Tubes were centrifuged for $2 \mathrm{~min}$ at $20000 \mathrm{xg}$ and the supernatant was discarded. The spore pellet was rinsed with $1 \mathrm{ml}$ of hexane and dried using a Speedvac concentrator. Samples were kept at $-20^{\circ} \mathrm{C}$ until DNA extraction was performed.

Samples were lysed by adding a 3-mm tungsten bead, 180 $\mu \mathrm{l}$ of Buffer ATL, and $1 \mu \mathrm{l}$ of Reagent DX (Qiagen, Valencia, CA, USA) to each sample and ground in a MixerMill 300. Samples were centrifuged and $20 \mu \mathrm{l}$ of Proteinase K added. Samples were incubated at $56^{\circ} \mathrm{C}$ overnight and DNA extraction was done the following day using the QIAamp DNA Micro kit (Qiagen).

Basidiospore counts were done using a ribosomal ITS TaqMan assay as described in Lamarche et al. (2016). Briefly, realtime PCR was performed using 1X QuantiTect ${ }^{\mathrm{TM}}$ Multiplex PCR NoROX Master Mix (Qiagen), 0.6 $\mu \mathrm{M}$ of each primer, $0.1 \mu \mathrm{M}$ of TaqMan probe and $1 \mu \mathrm{l}$ of template DNA, for a total volume of $10 \mu \mathrm{l}$. All reactions were on an Applied Biosystems 7500 Fast Real-Time PCR System (Life Technologies, Carlsbad, CA, USA). Basidiospore equivalents per rod were calculated by translating $\mathrm{Ct}$ values using standard curve equations. As conidia can be multinucleate (Hsiang et al. 1989), a selected mono-basidiosporal isolate of $H$. irregulare (\#98-008 confirmed with 1-2 nuclei/conidia), was used to generate standard curves with a correlation coefficient $\left(r^{2}\right)$ of 0.99 (Lamarche et al. 2016). 
Total amount of basidiospores sampled per $\mathrm{m}^{3}$ was calculated using: number of basidiospores per $\operatorname{rod} X 1000 \mathrm{~L} / \mathrm{m}^{3} / \mathrm{h}$ $/ 21.6 \mathrm{~L} / \mathrm{min}$ per $\operatorname{rod} \mathrm{X} 60 \mathrm{~min} / \mathrm{h} X 9.3 \mathrm{~h}$ (Fall et al. 2015). The amount of basidiospores $\mathrm{m}^{-2} \mathrm{~h}^{-1}$ for each week was calculated by dividing the weekly amount of basidiospores per $\mathrm{m}^{3}$ by 9.3 hours, assuming total basidiospores falling on the $\mathrm{m}^{2}$ crosssection was obtained by summing all spores in the $\mathrm{m}^{-3} \mathrm{~h}^{-1}$ above (Pfender et al. 2007). Total amount of basidiospores deposited on a $30-\mathrm{cm}$ stump was calculated using: total cumulative amount of basidiospores $\mathrm{m}^{-3}$ on site $\mathrm{X}$ (stump radius $^{2} \mathrm{X} \pi$ ), again assuming total basidiospores falling on the $\mathrm{m}^{2}$ cross-section was obtained by summing all spores in the $\mathrm{m}^{-3}$ above.

The relationship between weekly basidiospore counts and distance from the infected plantation was examined using a generalized linear model in R (R Core Team 2016) with a negative binomial error structure ( $\mathrm{R}$ function glm.nb, Venables and Ripley 2002).

\section{Results}

Basidiospore counts peaked during the fourth week of October 2014 (Table 1) with a total of 443 collected on the rods for that week. Highest total basidiospore count at one location was 405 in the infected plantation, which decreased to 88 basidiospores $500 \mathrm{~m}$ away, then to 80 basidiospores at $1.5 \mathrm{~km}$, down to 14 basidiospores $140 \mathrm{~km}$ from the infected plantation (Table 1). Total basidiospore density cumulated over six weeks was highest in the plantation with 33.4 basidiospores $\mathrm{m}^{-3}$, then 7.3 basidiospores $\mathrm{m}^{-3}$ at $500 \mathrm{~m}$, down to 1.2 basidiospore $\mathrm{m}^{-3}$ at $140 \mathrm{~km}$. In order to estimate the risk of infecting a stump, we calculated the cumulated basidiospore deposits on a $30-\mathrm{cm}$ stump. It was highest in the infected plantation with 2.4 basidiospores per stump, followed by 0.5 at $500 \mathrm{~m}, 0.5$ at $1.5 \mathrm{~km}$, and 0.1 at $140 \mathrm{~km}$.

The analysis conducted using the generalized linear model in $\mathrm{R}$ showed that there was a significant interaction between the effects of collection date and distance, i.e., the decline in basidiospore count with increasing distance was less pronounced at dates earlier and later than the peak during the week of October $24^{\text {th }}$. The dispersion parameter (theta value) of the model was 1.16, indicating a good fit.

\section{Discussion}

The cumulative aerial basidiospore density (33.4) was highest in the infected plantation and rapidly declined to 6.6 basidiospores $\mathrm{m}^{-3}$ at the site located $1.5 \mathrm{~km}$ away (Table 1 ). When translated in number of basidiospores deposited on a $30-\mathrm{cm}$ stump during that 6-week period, values fell steeply below 1.0 basidiospore (0.52) per stump at $500 \mathrm{~m}$ from the infected plantation. Edmonds and Driver (1974) also used an automated rotary arm spore collector and found deposition rates between 3 to 70 basidiospore $\mathrm{m}^{-2} \mathrm{~h}^{-1}$ in an infected Washington State forest, values that can be compared to our highest weekly values of $3.1 \mathrm{~m}^{-2} \mathrm{~h}^{-1}$ in the infected plantation and $0.4 \mathrm{~m}^{-2} \mathrm{~h}^{-1} 1.5 \mathrm{~km}$ away in the fourth week of October. Similarly, Gonthier et al. (2005) found deposit rates on fresh wood disks ranged from 169 to $15550 \mathrm{~m}^{-2} \mathrm{~h}^{-1}$ in Italian alpine forests where disease incidence ranged from $30 \%$ to $50 \%$. Punter (1970) measurements on fresh wood disks in Ontario found values between 0.1-2.1 basidiospores $\mathrm{m}^{-2} \mathrm{~h}^{-1}$. Most of the weekly values we observed were under $0.2 \mathrm{~m}^{-2} \mathrm{~h}^{-1}$, indicating that we were clearly at the early stages of the epidemic in Québec.

The rotary arm spore collector and the wood disk method measure different phenomena. Rotary arm collectors give the number of basidiospores per $\mathrm{m}^{3}$, whereas fresh wood disks indicate the actual number of viable infectious basidiospores per $\mathrm{m}^{2}$. The number of infections on a stump is lower than the actual number of basidiospores landing on the stump for various reasons (Gonthier et al. 2005), including environmental factors, virulence of fungal isolates, competition with other fungi, and the ability of the host to fence off the colo-

Table 1. Number of $H$. irregulare spores collected weekly in the Sainte-Clotilde-de-Horton plantation at $0.5 \mathrm{~km}, 1.5 \mathrm{~km}, 5 \mathrm{~km}$, $25 \mathrm{~km}$ and $140 \mathrm{~km}$.

\begin{tabular}{|c|c|c|c|c|c|c|c|}
\hline & \multicolumn{6}{|c|}{ Distance from infected plantation (in km) } & \multirow[b]{2}{*}{ Weekly total } \\
\hline & 0 & 0.5 & 1.5 & 5 & 25 & 140 & \\
\hline \multicolumn{8}{|l|}{ Sampling week } \\
\hline Oct. 3,2014 & $2780^{*}$ & $3(0.03)^{1}$ & $6(0.06)$ & $4(0.04)$ & 0 & $1(0.01)$ & 14 \\
\hline Oct. 10, 2014 & $1584^{*}$ & $7(0.06)$ & $\mathrm{n} / \mathrm{a}$ & $8(0.07)$ & $3(0.03)$ & $\mathrm{n} / \mathrm{a}$ & 18 \\
\hline Oct. 17,2014 & $\mathrm{n} / \mathrm{a}^{2}$ & $3(0.03)$ & $5(0.044)$ & $4(0.04)$ & $11(0.09)$ & $6(0.06)$ & 29 \\
\hline Oct. 24,2014 & $345(3.05)$ & $33(0.29)$ & $45(0.39)$ & $2(0.02)$ & $11(0.09)$ & $7(0.06)$ & 443 \\
\hline Oct. 31, 2014 & $47(0.42)$ & $30(0.27)$ & $19(0.17)$ & $16(0.01)$ & $2(0.02)$ & $\mathrm{n} / \mathrm{a}$ & 114 \\
\hline Nov. 7, 2014 & $13(0.12)$ & $12(0.11)$ & $5(0.04)$ & $3(0.03)$ & $1(0.01)$ & $\mathrm{n} / \mathrm{a}$ & 34 \\
\hline Total spore count & 405 & 88 & 80 & 37 & 28 & 14 & \\
\hline Cumulative count $\mathrm{m}^{-3}$ & 33.41 & 7.26 & 6.60 & 3.05 & 2.31 & 1.16 & \\
\hline $\begin{array}{l}\text { Cumulative spores deposited } \\
\text { on a } 30-\mathrm{cm} \text { stump }\end{array}$ & 2.37 & 0.52 & 0.46 & 0.22 & 0.16 & 0.08 & \\
\hline
\end{tabular}

${ }^{1}$ Values in brackets indicate spore deposition per $\mathrm{m}^{-2} \mathrm{~h}^{-1}$ for the 7 -day period.

${ }^{2}$ n/a: not available.

*Values from deposition inside the infected plantation that were interpreted as H. irregulare conidia and were not considered in analysis. 
nization process. Rishbeth (1959) reported that aerial basidiospore viability varied between $1 \%$ and $5 \%$. It is not known how many basidiospores are needed to actually initiate an infection on a fresh stump but extrapolation of Gonthier et al. (2005) data suggests that a deposition rate of 5 basidiospores $\mathrm{m}^{-2} \mathrm{~h}^{-1}$ is needed to initiate infection on stumps. Applied to our experimental design, this would represent approximately 356 basidiospores per $30-\mathrm{cm}$ stump over six weeks. In Ontario, Punter (1970) observed that successful stump infection was rare when basidiospores were trapped on wood disks at a rate lower than 100 basidiospores $\mathrm{m}^{-2} \mathrm{~h}^{-1}$. Compared to the rotary arm spore collector method, wood disk trapping has the advantage of providing actual infection per $\mathrm{m}^{-2} \mathrm{~h}^{-1}$ but it is very labour intensive. Rotary arm spore collectors are efficient at collecting spores from any fungal species that can be identified using next generation sequencing methods, thus making it possible to study multiple tree disease fungi simultaneously.

Kallio (1970) demonstrated that $99.9 \%$ of Heterobasidion basidiospores were deposited within $100 \mathrm{~m}$ from the fruiting body. Our model shows a similar decrease in the number of basidiospores with an increase in distance from the infected plantation. At $5 \mathrm{~km}$, the number of basidiospores deposited on a $30-\mathrm{cm}$ stump was 0.22 , a value similar to those found at $25 \mathrm{~km}$ and $140 \mathrm{~km}$. Since a single Heterobasidion basidiospore might travel as far as $500 \mathrm{~km}$ (Kallio 1970), this may represent the background basidiospore load resulting from long-distance dispersal. While it is not known the basidiospore threshold required to trigger an infection on a freshly cut stump, it is unlikely that local basidiospores can be an added risk of infection more than $5 \mathrm{~km}$ away. However, the low basidiospore density observed as the background basidiospore load is still high enough to be responsible for past infections in Québec.

Early readings of 2780 and 1584 spores per week in the plantation during October 3 and October 10, 2014, were interpreted as Heterobasidion conidia and were not considered in the analysis since spore count numbers at $500 \mathrm{~m}$ and $1.5 \mathrm{~km}$ from the plantation were low during those weeks. Only very small sporophores were visible in the plantation at that time. Even though conidia were reported to be more resistant than basidiospores to ultraviolet light and high temperatures (Kallio 1970), the aerial dissemination range and seasonal production of conidia is unknown.

Eastward winds are dominant in Québec and we hypothesized that an eastern transect would best capture basidiospore dispersal from an infected plantation. Due to shifting winds and the absence of meteorological data for the site, we do not know how effective we were at catching basidiospores from the infected plantation, therefore a freshly thinned plantation located directly downwind from an infected site may be more at risk than what was estimated here.

As the number of known infected plantations is presently low in the province and basidiospore density rapidly decreases with distance, long-distance aerial basidiospore dispersal will remain for a while the most important constant source of infectious $H$. irregulare basidiospores in the province. Literature indicates freshly cut stumps are infection courts in the first two weeks (Cobb and Schmidt 1964, Ross
1968) and for this reason, thinning is not recommended during summer and fall when spores may be present. This twoweek threshold is explained by the crust of resin that forms after that period, possibly inhibiting spore penetration. However, cold temperatures during late fall and winter thinning can reduce resin formation and lead to infection during warmer winter periods, suggesting that late fall and winter thinning is not an absolute control method.

Despite the very low risk level associated with the calculated number of basidiospores deposited on a 30-cm stump in this study, the large number of trees thinned annually warrants that stump treatment (Dumas and Laflamme 2013) with the biological control agent Rotstop ${ }^{\circledR} \mathrm{C}$ (BioForest Technologies Inc., Sault Ste. Marie, ON) is still the best strategy, especially in valuable plantations. In future experiments we will deploy across the southern province of Québec new rotary arm spore collectors to achieve year-long weekly monitoring.

\section{Acknowledgements}

We thank Gaston Laflamme and Josyanne Lamarche for their constructive review of the manuscript, and Jacques Turcotte for hosting a spore sampler.

\section{References}

Cobb, F.W. and R.A. Schmidt. 1964. Duration of susceptibility of eastern white pine stumps to Fomes annosus. Phytopathology 54(10): 1216.

Dumas, M.T. and G. Laflamme. 2013. Efficacy of two Phlebiopsis gigantea formulations in preventing Heterobasidion irregulare colonization of red pine stumps in eastern Canada. Phytoprotection 93(1): 25-31.

Edmonds, R.L. and C.H. Driver. 1974. Dispersion and deposition of spores of Fomes annosus and fluorescent particles. Phytopathology 64: 1313-1321.

Fall, M.L., D.M. Tremblay, M. Gobeil-Richard, J. Couillard, H. Rocheleau, H. Van der Heyden, C.A. Lévesque, C. Beaulieu and O. Carisse. 2015. Infection efficiency of four Phytophthora infestans clonal lineages and DNA-based quantification of sporangia. PloS One 10(8): e0136312.

Gonthier, P., M.M. Garbelotto and G. Nicolotti. 2005. Seasonal patterns of spore deposition of Heterobasidion species in four forests of the western Alps. Phytopathology 95(7): 759-767.

Hsiang, T., R.L. Edmonds and C.H. Driver. 1989. Conidia of Heterobasidion annosum from Tsuga heterophylla forests in western Washington. Can. J.Bot. 67(4): 1262-1266.

Jorgensen, E. 1956. Fomes annosus (Fr.) Cke. on red pine in Ontario. Forest. Chron. 32 (1): 86-88.

Kallio, T. 1970. Aerial distribution of the root rot fungus Fomes annosus (FR.) Cooke in Finland. Acta For. Fenn. 107: 1-55

Laflamme, G. and R. Blais. 1995. Détection du Heterobasidion annosum au Québec. Phytoprotection 76 (1): 39-43.

Lamarche, J., A. Potvin, D. Stewart, M. Blais, G. Pelletier, S.F. Shamoun, R.C. Hamelin and P. Tanguay. 2016. Real-time PCR assays for the detection of Heterobasidion irregulare, H. occidentale, $H$. annosum sensu stricto and the Heterobasidion annosum complex. For. Path. doi:10.1111/efp.12321.

MFFP. 2015. Provincial insect and disease plantation surveillance database. Ministère des Forêts, de la Faune et des Parcs du Québec, Québec, QC, Canada.

MFFP. 2016. La maladie du rond. Direction de la protection des forêts, Ministère des Forêts, de la Faune et des Parcs, Québec, QC, Canada. Available from https://mffp.gouv.qc.ca/forets/fimaq/insectes/ fimaq-insectes-maladies-rond.jsp (Accessed January 24 2017). 
Pfender, W., R. Graw, W. Bradley, M. Carney and L. Maxwell. 2007. Emission rates, survival, and modeled dispersal of viable pollen of creeping bentgrass. Crop Sci. 47(6): 2529-2539.

Punter, D. 1970. Fomes annosus in eastern Canada. In: T.A. Toussoun, R.V. Bega and P.E. Nelson (eds): Root diseases and soil-borne pathogens. pp. 156-160. University of California Press, Berkeley, CA. USA.

R Core Team. 2016. R: A language and environment for statistical computing. R Foundation for Statistical Computing, Vienna, Austria. Available from: http://www. R-project. Org (accessed January 24 2017)

Rishbeth, J. (1959). Dispersal of Fomes annosus Fr. and Peniophora gigantea (Fr.) Massee. Trans. Brit. Mycol. Soc. 42(2): 243-260.

Ross, E. W. 1968. Duration of stump susceptibility of Loblolly pine to infection by Fomes annosus. Forest Sci. 14(2): 206-211.
Sippell, W.L., H.L. Gross and A.H. Rose. 1968. Ontario region: Important forest diseases. In: Annual report of the forest insect and disease survey. pp. 66-76. Dept. of Fisheries and Forestry, Ottawa, ON Canada.

Stambaugh, W.J., F.W. Cobb Jr., R.A. Schmidt and F.C. Krieger. 1962. Seasonal inoculum dispersal and white pine stump invasion by Fomes annosus. Plant Dis. Rep 46: 194-198.

Venables, W.N. and B.D. Ripley. 2002. Modern applied statistics with S. 4th ed. Springer, New York, NY, USA.

Vollbrecht, G., U. Johansson, H. Eriksson and J. Stenlid. 1995. Butt rot incidence, yield and growth pattern in a tree species experiment in southwestern Sweden. For. Ecol. Manag. 76(1): 87-93. 